\title{
Pola Penyakit Tidak Menular dan Faktor Risikonya pada Suku Anak Dalam di Desa Nyogan Provinsi Jambi
}

\section{Patterns of Non-Communicable Disease and Risk Factors of Anak Dalam Ethnic Group in Nyogan Village Jambi Province}

\author{
Ummi Kalsum*, Oka Lesmana, Diah Restu Pertiwi \\ Fakultas Kesehatan Masyarakat, Universitas Jambi \\ ("ummi2103@unja.ac.id)
}

\begin{abstract}
ABSTRAK
Hipertensi dan Diabetes Mellitus (DM) semakin meningkat prevalensinya dan merupakan penyebab utama kematian di Indonesia, hal tersebut juga terjadi di Jambi. Transisi lingkungan dan sosial yang terjadi pada Suku Anak Dalam (SAD) di Desa Nyogan sejak tahun 2004 mengakibatkan perubahan gaya hidup dan berdampak pada perubahan pola penyakit. Tujuan penelitian ini mengetahui faktor yang berhubungan dengan kejadian hipertensi dan DM pada SAD Desa Nyogan. Desain penelitian adalah cross sectional menggunakan total sampel 193 orang SAD, berusia $\geq 18$ tahun yang tinggal di permukiman SAD Desa Nyogan. Pengumpulan data selama bulan April 2019. Variabel penelitian adalah usia, jenis kelamin, riwayat keluarga, pola makan, merokok dan aktivitas fisik diperoleh dengan wawancara dan pengukuran tekanan darah serta pemeriksaan gula darah. Analisis menggunakan uji chi-square dan regresi logistik ganda. Penelitian menemukan prevalensi hipertensi 4,32\% dan DM 0,72\%. Faktor risiko hipertensi adalah usia dan pola makan, sedangkan DM adalah usia, jenis kelamin, riwayat keluarga, pola makan dan aktivitas fisik. Faktor paling dominan terhadap hipertensi adalah usia $(\mathrm{OR}=4,632 ; 95 \% \mathrm{CI}=1,579-13,675)$ dan terhadap penyakit $\mathrm{DM}$ adalah pola makan $(\mathrm{OR}=11,23 ; 95 \% \mathrm{CI}=0,84-$ 150,57). SAD perlu mengatur pola makan, terutama saat usia telah memasuki $>40$ tahun dan bergaya hidup sehat. Kata kunci: Hipertensi, DM, SAD, PTM, transisi

ABSTRACT

Hypertension and Diabetes Mellitus (DM) are increasingly prevalent and the main cause of death in Indonesia, this also happened in Jambi. The environmental and social transition that occurred in Anak Dalam Ethnic Group in Nyogan Village since 2004 has resulted to lifestyle changes and has an impact on changing patterns of disease. The purpose of this study was to determine risk factors related to hypertension and DM in SAD Nyogan Village. The research design was cross sectional used a total sample of 193 SAD, aged $\geq 18$ years-old, living in the SAD residential area of Nyogan Village. Time of data collection during April 2019. Research variables were age, gender, family history, diet, smoking and physical activity obtained by interviews, blood pressure measurements and glucose checks. Data analysis using chi-square and multiple logistic regression. The study found the prevalence of hypertension in SAD 4,32\% and DM were 0,72\%. Risk factors of hypertension were age and diet, while DM were age, sex, family history, diet and physical activity. The most dominant factor related to hypertension was age (Odds Ratio (OR=4,632; 95\% Confidence Interval $(C I)=1,579-13,675)$ and the most dominant factor of $D M$ was a diet $(O R=11,23 ; 95 \% C I=0,84-150,57)$. The SAD needs to regulate their diet, especially when they are $>40$ years-old and also carry out a healthy lifestyle. Keywords: Hypertension, DM, SAD, non-communicable, transition
\end{abstract}




\section{PENDAHULUAN}

Permasalahan kesehatan masyarakat saat ini adalah double burden diseases, yaitu keadaan ketika Penyakit Tidak Menular (PTM) terus bertambah, namun penyakit menular juga masih belum terberantas. Terjadinya pergeseran dari penyakit menular menjadi tidak menular, misalnya penyakit kardiovaskular, kanker, hipertensi dan diabetes. ${ }^{1}$

Hipertensi dapat menimbulkan kerusakan pada ginjal, jantung dan otak bila tidak dideteksi secara dini. ${ }^{2}$ Diabetes Mellitus (DM) dapat meningkatkan risiko penyakit jantung, stroke, kebutaan dan sebagainya. ${ }^{3}$ Hipertensi mengakibatkan kematian sekitar delapan juta orang setiap tahun, diantaranya 1,5 juta kematian terjadi di Asia Tenggara yang $1 / 3$ populasinya menderita hipertensi. ${ }^{4}$ Kasus diabetes pada orang dewasa terdapat sebanyak 415 juta orang diabetes $(8,5 \%)$ pada tahun 2015. ${ }^{5}$ Prevalensi hipertensi dan DM di Indonesia mengalami peningkatan yaitu prevalensi hipertensi 25,8\% (2013) menjadi 34,1\% (2018) dan prevalensi DM sebesar 1,5\% (2013) menjadi 2,0\% (2018). ${ }^{6,7}$ Prevalensi Hipertensi di Provinsi Jambi sebesar 24,6\% dan prevalensi DM sebesar $1,1 \%{ }^{6}$ Kondisi di Kabupaten Muaro Jambi juga terus mengalami peningkatan selama tiga tahun terakhir yaitu sebesar 4,19\% (2015), 4,28\% (2016) menjadi $4,79 \%$ (2018). ${ }^{8,9,10}$

Berdasarkan data diatas, terlihat adanya kecenderungan peningkatan prevalensi penyakit tidak menular yang disebabkan oleh transisi epidemiologi, yang dimulai dari dominasi penyakit menular dan diakhiri dengan dominasi penyakit tidak menular. Salah satu penyebabnya adalah perubahan sosial, yang saat ini tengah terjadi pada komunitas adat terpencil atau yang dikenal sebagai Suku Anak Dalam (SAD) yang sebelumnya nomaden, kini telah memiliki hunian tetap..$^{11,12}$ Sehingga diduga telah mengalami perubahan pola penyakit dari penyakit infeksi menjadi penyakit tidak menular seperti hipertensi dan diabetes mellitus. Data dari Dinas Sosial Tenaga Kerja dan Transmigrasi tahun 2010 populasi Suku Anak Dalam (SAD) yang sudah dibina dan yang belum dibina dari tahun 1973 sampai tahun 2010 sebanyak $6.733 \mathrm{KK}$ atau 28.883 jiwa yang tersebar di 8 kabupaten, salah satunya yaitu di Kabupaten Muaro Jambi tepatnya di Desa Nyogan. Desa Nyogan terdiri dari 4 Dusun, yaitu Dusun Nyogan, Jerat
Harimau, Nebang Parah dan Selapik. Karakteristik masyarakat Desa Nyogan $60 \%$ terdiri dari SAD dan telah memiliki hunian tetap sejak tahun 2004 yang terkonsentrasi di Dusun Nyogan, yang berarti telah 14 tahun mendiami hunian tetap, sehingga mengalami perubahan gaya hidup yang berdampak pada perubahan pola penyakit yang mulai diderita. ${ }^{13}$

Pola penyakit yang sering diderita SAD pada umumnya berupa penyakit infeksi, yaitu cacingan, kurang gizi, borok/kudis, batuk, diare, demam malaria (kuro), sakit perut, penyakit pernapasan, panu dan kadas. ${ }^{13}$ Namun, adanya transisi epidemiologi (lingkungan dan sosial), ada kemungkinan SAD mengalami perubahan pola penyakit, dari penyakit infeksi menjadi penyakit tidak menular seperti hipertensi dan diabetes mellitus. Penelitian sebelumnya pada SAD di Desa Sungai Terap, Kecamatan Bathin XXIV menunjukkan bahwa SAD memiliki faktor risiko terkait penyakit tidak menular yaitu merokok, suka mengonsumsi minuman manis, pola makan rendah serat dan makanan berlemak. ${ }^{14}$

Hasil penelitian menunjukkan bahwa faktor risiko yang paling banyak berperan terhadap kejadian hipertensi adalah usia, jenis kelamin, riwayat keluarga, pola makan, merokok dan aktivitas fisik. Usia $\geq 40$ tahun berisiko mengidap hipertensi dan lebih banyak diderita oleh perempuan dibandingkan laki-laki. ${ }^{15}$ Seseorang yang mempunyai riwayat keluarga hipertensi berkemungkinan mengidap hipertensi. ${ }^{16,17}$ Terkait pola makan, asupan lemak lebih dan natrium berpengaruh terhadap kejadian hipertensi. ${ }^{18}$ Seseorang yang memiliki kebiasaan merokok dan tidak memiliki kebiasaan berolahraga berisiko terkena hipertensi. ${ }^{19}$

Faktor risiko yang paling banyak berperan terhadap kejadian DM tipe II adalah usia, jenis kelamin, riwayat keluarga, pola makan, merokok dan aktivitas fisik. Penderita diabetes mellitus tipe II sebesar $90-95 \%$ biasanya berumur $\geq 45$ tahun. ${ }^{20}$ Perempuan lebih banyak menderita DM dibandingkan laki-laki. ${ }^{21}$ Seseorang yang memiliki riwayat keluarga DM berisiko mengidap penyakit tersebut. ${ }^{19}$ Seseorang dengan pola makan yang tidak baik terdiagnosa menderita DM tipe II disertai komplikasi, serta jumlah makanan yang dikonsumsi masyarakat mempengaruhi diabetes. ${ }^{22}$ Seseorang yang memiliki kebiasaan merokok be- 
risiko untuk menderita diabetes mellitus tipe $\mathrm{II},{ }^{23}$ juga pada orang yang jarang berolahraga berisiko menderita diabetes. ${ }^{24}$

Penelitian yang dilakukan pada penduduk asli Fulani tentang epidemiologi hipertensi menunjukkan faktor risiko hipertensi grade 1, 2 dan 3 adalah jenis kelamin, merokok dan riwayat keluarga ${ }^{25}$ Penelitian tentang diabetes tipe II pada orang Aborigin ditemukan penderita diabetes dengan komplikasi dibandingkan populasi umum, dengan faktor risiko merokok, obesitas, dan hipertensi. ${ }^{26}$ Penelitian tentang pola penyakit tidak menular pada SAD di Jambi, belum pernah dilakukan, utamanya dalam mencermati perubahan pola hidup pada komunitas SAD yang sudah menetap pada sebuah dusun serta faktor risikonya. Tujuan penelitian ini adalah untuk menganalisis besar masalah dan faktor risiko penyakit tidak menular pada Suku Anak Dalam di Desa Nyogan, Kabupaten Muaro Jambi.

\section{BAHAN DAN METODE}

Desain penelitian ini adalah cross sectional yang dilakukan di Desa Nyogan, Kabupaten Muaro Jambi. Waktu pengumpulan data selama bulan April 2019. Populasi dalam penelitian ini adalah suku anak dalam berusia $\geq 18$ tahun sebanyak 203 orang. Adapun sampel pada penelitian ini adalah SAD yang memenuhi kriteria inklusi (SAD atau keturunan SAD satu tingkat baik ayah atau ibunya, bersedia menjadi responden dan tinggal di wilayah permukiman trans-sosial Suku Anak Dalam Desa Nyogan) dan kriteria eksklusi (sedang hamil, sedang mengonsumsi obat-obatan tertentu yang meningkatkan tekanan darah serta mengonsumsi alkohol) sebanyak 193 orang. Jumlah sampel ini sesuai dengan jumlah sampel minimal yang dibutuhkan untuk penelitian ini yang dihitung dengan rumus Lemeshow dan Lwanga untuk uji hipotesis beda proporsi dua populasi berjumlah 193 menggunakan $\alpha=5 \% ; \beta=20 \%$ dan proporsi kejadian penyakit $(p)=0,5$. Keterbatasan populasi SAD yang tinggal pada lokasi Desa Trans-sosial (Dusun Nyogan) yang sudah menetap sejak tahun 2004 (tidak nomaden lagi), yang memenuhi kriteria inklusi dan eksklusi, maka seluruhnya diambil sebagai sampel (total sampling).

Pengumpulan data melalui wawancara dan pengukuran langsung. Variabel usia, jenis ke- lamin, riwayat keluarga, pola makan, merokok dan aktivitas fisik dikumpulkan dengan cara wawancara, sedangkan variabel terikat yaitu hipertensi dan DM dikumpulkan dengan melakukan pengukuran tekanan darah menggunakan tensi meter digital dan pengukuran kadar gula darah sewaktu memakai alat cek gula darah digital. Wawancara dilakukan oleh tim enumerator sebanyak 6 orang yang telah dilatih oleh tim peneliti, berasal dari mahasiswa Semester VI dan VIII Fakultas Kesehatan Masyarakat Universitas Jambi. Pola makan dilakukan wawancara menggunakan Semi Food Frequency Questionnaire. Pengukuran tensi dan gula darah dilakukan oleh tenaga kesehatan profesional yang direkrut untuk kepentingan penelitian ini yaitu bidan Desa Nyogan yang juga telah diberikan pelatihan oleh tim peneliti. Analisis data menggunakan uji chi-square dengan alternatif uji exact fisher dan continuity correction serta regresi logistic ganda yang menghasilkan model akhir faktor risiko yang paling dominan terhadap hipertensi dan DM pada tingkat kepercayaan $95 \%$.

Penyajian data secara tekstular, tabular dan grafikal. Prevalensi dan proporsi kejadian penyakit disajikan menggunakan grafik, sedangkan hasil analisis univariat dengan distribusi frekuensi dan hasil analisis bivariat dengan menyajikan perbandingan proporsi menurut variabel, ukuran asosiasi dengan angka prevalence ratio dan $95 \%$ confidence interval serta nilai probability. Analisis multivariat disajikan menggunakan tabel model akhir yang berisi variabel yang berkontribusi terhadap penyakit Hipertensi dan DM.

\section{HASIL}

Distribusi responden menurut karakteristik sosiodemografi yaitu rata-rata usia 38 tahun, minimum 18 tahun dan maksimum 90 tahun. Rata-rata jumlah anggota rumah tangga 4 orang. Distribusi laki-laki dan perempuan hampir sama. Sebagian besar responden sudah menikah. Pendidikan tergolong rendah (tidak sekolah/tamat SD/tamat SMP sederajat) dengan mayoritas pekerjaannya adalah petani/nelayan/buruh. Sebagian besar responden berpendapatan rendah (Tabel 1). Rata-rata skor konsumsi pangan responden adalah 214,59 dan rata-rata jumlah kalori 971,4 kkal. Responden yang merokok rata-rata mengonsumsi rokok hampir 16 batang per hari. Aktivitas fisik ringan 
Tabel 1. Karakteristik Responden

\begin{tabular}{|c|c|c|}
\hline Karakteristik & $\bar{n}$ & $\%$ \\
\hline \multicolumn{3}{|l|}{ Usia } \\
\hline$<40$ tahun & 118 & 61,1 \\
\hline$\geq 40$ tahun & 75 & 38,9 \\
\hline \multicolumn{3}{|l|}{ Jenis Kelamin } \\
\hline Laki-laki & 93 & 48,2 \\
\hline Perempuan & 100 & 51,8 \\
\hline \multicolumn{3}{|l|}{ Status Perkawinan } \\
\hline Tidak Kawin & 32 & 16,6 \\
\hline Kawin & 161 & 83,4 \\
\hline \multicolumn{3}{|l|}{ Pendidikan } \\
\hline Menengah & 12 & 6,2 \\
\hline Rendah & 181 & 93,8 \\
\hline \multicolumn{3}{|l|}{ Pekerjaan } \\
\hline Pegawai Swasta/Wiraswasta & 56 & 29,0 \\
\hline Petani/Nelayan/Buruh & 129 & 66,8 \\
\hline IRT/Tidak Bekerja/Lainnya & 8 & 4,1 \\
\hline \multicolumn{3}{|l|}{ Jumlah ART } \\
\hline Kecil & 159 & 82,4 \\
\hline Besar & 34 & 17,6 \\
\hline \multicolumn{3}{|l|}{ Pendapatan } \\
\hline Tinggi & 6 & 3,1 \\
\hline Rendah & 187 & 96,9 \\
\hline \multicolumn{3}{|l|}{ Riwayat Keluarga Hipertensi } \\
\hline Ya & 25 & 13,0 \\
\hline Tidak & 168 & 87,0 \\
\hline \multicolumn{3}{|c|}{ Riwayat Keluarga Diabetes Mellitus Tipe II } \\
\hline $\mathrm{Ya}$ & 7 & 3,6 \\
\hline Tidak & 186 & 96,4 \\
\hline \multicolumn{3}{|l|}{ Pola Makan } \\
\hline Baik & 153 & 79,3 \\
\hline Tidak Baik & 40 & 20,7 \\
\hline \multicolumn{3}{|l|}{ Merokok } \\
\hline $\mathrm{Ya}$ & 91 & 47,2 \\
\hline Tidak & 102 & 52,8 \\
\hline \multicolumn{3}{|l|}{ Aktivitas Fisik } \\
\hline Aktif & 117 & 60,6 \\
\hline Kurang Aktif & 76 & 39,4 \\
\hline
\end{tabular}

Sumber: Data Primer, 2019

rata-rata responden melakukan 270,26 menit per hari dan untuk aktivitas fisik sedang 196 menit per hari, sedangkan untuk rata-rata aktivitas fisik berat yaitu 3539,7 MET minute (tabel tidak disajikan). Proporsi kejadian Hipertensi 9,3\% dengan prevalensi 4,32\% sedangkan proporsi DM 1,6\% dengan prevalensi 0,72\% (Gambar 1).

Karakteristik responden lebih banyak pada usia $<40$ tahun $(61,1 \%)$, perempuan $(51,8 \%)$, sudah kawin $(83,4 \%)$ dengan pendidikan rendah $(93,8 \%)$. Pekerjaan terbanyak sebagai Petani/Ne-
layan/Buruh (66,8\%), memiliki jumlah anggota rumah tangga dalam kategori kecil $(82,4 \%)$ dan berpendapatan rendah $(96,9 \%)$. Kebanyakan keluarga SAD tidak mempunyai riwayat hipertensi $(87,0 \%)$ dan tidak punya riwayat DM $(96,4 \%)$. Pola makan SAD kebanyakan dalam kategori baik (79,3\%). Distribusi responden merokok dan tidak merokok hampir merata. SAD yang aktif dalam melakukan aktivitas fisik sebesar 60,6\% (Tabel 1). Hasil analisis bivariat menemukan ada hubungan antara usia dengan kejadian hipertensi. 


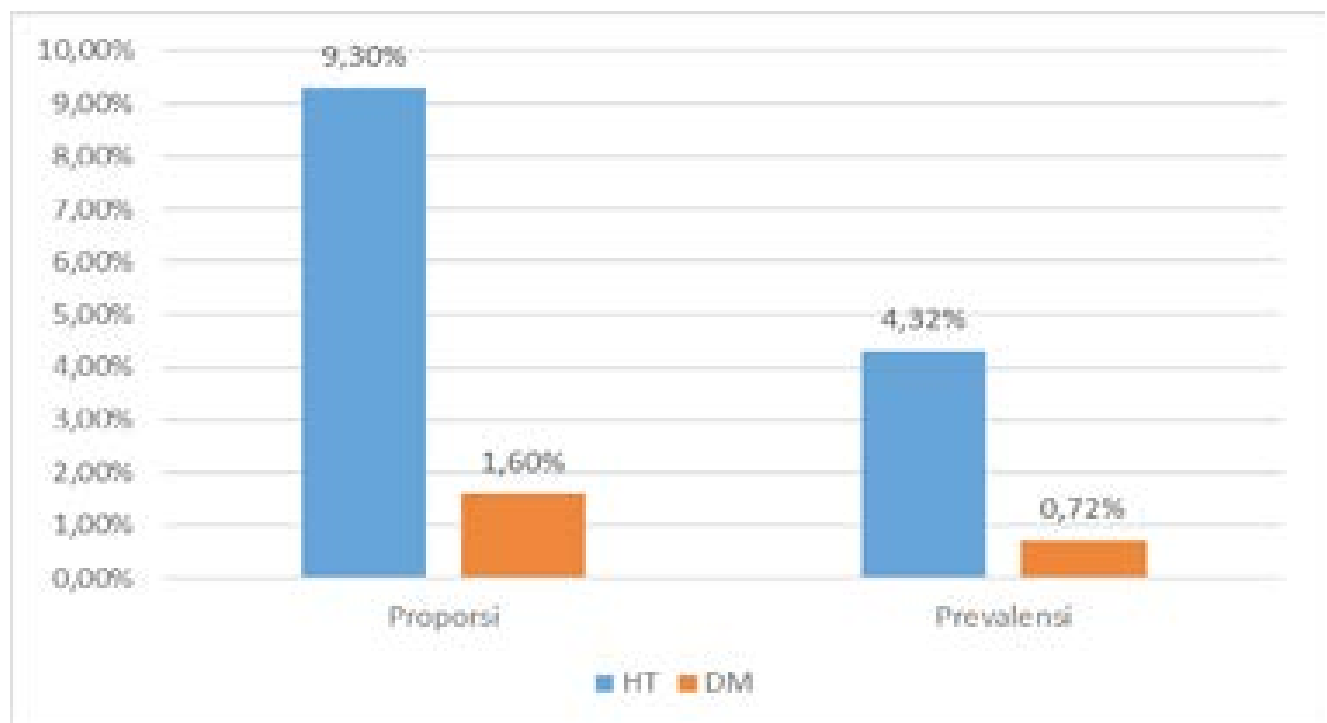

Gambar 1. Proporsi dan Prevalensi Hipertensi dan DM Tipe II pada SAD di Desa Nyogan

Tabel 2. Faktor Risiko terhadap Hipertensi pada SAD di Desa Nyogan

\begin{tabular}{|c|c|c|c|c|c|c|c|c|}
\hline \multirow{3}{*}{ Variabel } & \multicolumn{4}{|c|}{ Hipertensi } & \multirow{2}{*}{\multicolumn{2}{|c|}{ Total }} & \multirow{3}{*}{ POR (95\% CI) } & \multirow{3}{*}{ p value } \\
\hline & \multicolumn{2}{|c|}{ Ya } & \multicolumn{2}{|c|}{ Tidak } & & & & \\
\hline & $\mathbf{n}$ & $\%$ & n & $\%$ & n & $\%$ & & \\
\hline \multicolumn{9}{|l|}{ Umur } \\
\hline$\geq 40$ tahun & 13 & 17,3 & 62 & 82,7 & 75 & 100 & $4,73(1,614-13,911)$ & $0,005^{*}$ \\
\hline$<40$ tahun & 5 & 4,2 & 113 & 95,8 & 118 & 100 & & \\
\hline \multicolumn{9}{|l|}{ Jenis Kelamin } \\
\hline Perempuan & 8 & 8,0 & 92 & 92,0 & 100 & 100 & $0,72(0,272-1,915)$ & 0,682 \\
\hline Laki-laki & 10 & 10,8 & 83 & 89,2 & 93 & 100 & & \\
\hline \multicolumn{9}{|l|}{ Riwayat Keluarga } \\
\hline $\mathrm{Ya}$ & 2 & 8,0 & 23 & 92,0 & 25 & 100 & $0,82(0,178-3,830)$ & 1,000 \\
\hline Tidak & 16 & 9,5 & 152 & 90,7 & 168 & 100 & & \\
\hline \multicolumn{9}{|l|}{ Pola Makan } \\
\hline Tidak Baik & 5 & 12,5 & 35 & 87,5 & 40 & 100 & $1,53(0,514-4,603)$ & 0,540 \\
\hline Baik & 13 & 8,5 & 140 & 91,5 & 153 & 100 & & \\
\hline \multicolumn{9}{|l|}{ Merokok } \\
\hline Ya & 9 & 9,9 & 82 & 90,1 & 91 & 100 & $1,13(0,430-2,993)$ & 0,995 \\
\hline Tidak & 9 & 8,8 & 93 & 91,2 & 102 & 100 & & \\
\hline \multicolumn{9}{|l|}{ Aktivitas Fisik } \\
\hline Kurang Aktif & 6 & 7,9 & 70 & 92,1 & 76 & 100 & $0,75(0,269-2,092)$ & 0,766 \\
\hline Aktif & 12 & 10,3 & 105 & 89,7 & 117 & 100 & & \\
\hline
\end{tabular}

Sumber: Data Primer, 2019

Seseorang yang berusia $\geq 40$ tahun memiliki risiko hampir 5 kali lebih besar untuk menderita hipertensi dibandingkan yang berusia $<40$ tahun. Namun, tidak terbukti berhubungan antara variabel jenis kelamin, riwayat keluarga, pola makan, merokok dan aktivitas fisik terhadap kejadian hipertensi (Tabel 2). Secara statistik belum terbukti ada hubungan antara usia, jenis kelamin, riwayat keluarga, pola makan, merokok dan aktivitas fisik dengan kejadian DM. Namun, terlihat bahwa ada kecenderungan responden yang berusia $>=40$ tahun, pola makan tidak baik, merokok memperbesar risiko terjadinya DM (Tabel 3).

Model akhir yang terbentuk terhadap faktor 
Tabel 3. Faktor Risiko terhadap Diabetes Mellitus Tipe II pada SAD di Desa Nyogan

\begin{tabular}{|c|c|c|c|c|c|c|c|c|}
\hline \multirow{3}{*}{ Variabel } & \multicolumn{4}{|c|}{ Hipertensi } & \multirow{2}{*}{\multicolumn{2}{|c|}{ Total }} & \multirow{3}{*}{ POR (95\% CI) } & \multirow{3}{*}{ p value } \\
\hline & \multicolumn{2}{|c|}{ Ya } & \multicolumn{2}{|c|}{ Tidak } & & & & \\
\hline & $\mathbf{n}$ & $\%$ & $\mathbf{n}$ & $\%$ & $\mathbf{n}$ & $\%$ & & \\
\hline \multicolumn{9}{|l|}{ Umur } \\
\hline$\geq 40$ tahun & 2 & 2,7 & 73 & 97,3 & 75 & 100 & \multirow[t]{2}{*}{$3,20(0,286-35,983)$} & \multirow[t]{2}{*}{0,561} \\
\hline$<40$ tahun & 1 & 0,8 & 117 & 99,2 & 118 & 100 & & \\
\hline \multicolumn{9}{|l|}{ Jenis Kelamin } \\
\hline Perempuan & 1 & 1,0 & 99 & 99,0 & 100 & 100 & \multirow[t]{2}{*}{$0,46(0,041-5,514)$} & \multirow[t]{2}{*}{0,610} \\
\hline Laki-laki & 2 & 2,2 & 91 & 97,8 & 93 & 100 & & \\
\hline \multicolumn{9}{|l|}{ Riwayat Keluarga } \\
\hline $\mathrm{Ya}$ & 0 & 0,0 & 7 & 100 & 7 & 100 & \multirow[t]{2}{*}{ NA } & \multirow[t]{2}{*}{1,000} \\
\hline Tidak & 3 & 1,6 & 183 & 98,4 & 186 & 100 & & \\
\hline \multicolumn{9}{|l|}{ Pola Makan } \\
\hline Tidak Baik & 2 & 5,0 & 38 & 95,0 & 40 & 100 & \multirow[t]{2}{*}{$8,00(0,707-90,556)$} & \multirow[t]{2}{*}{0,110} \\
\hline Baik & 1 & 0,7 & 152 & 99,3 & 153 & 100 & & \\
\hline \multicolumn{9}{|l|}{ Merokok } \\
\hline $\mathrm{Ya}$ & 2 & 2,2 & 89 & 97,8 & 91 & 100 & \multirow[t]{2}{*}{$2,27(0,202-25,456)$} & \multirow[t]{2}{*}{0,603} \\
\hline Tidak & 1 & 1,0 & 101 & 99,0 & 102 & 100 & & \\
\hline \multicolumn{9}{|l|}{ Aktivitas Fisik } \\
\hline Kurang Aktif & 1 & 1,3 & 75 & 98,7 & 76 & 100 & \multirow[t]{2}{*}{$0,76(0,068-8,605)$} & \multirow[t]{2}{*}{1,000} \\
\hline Aktif & 2 & 1,7 & 115 & 98,3 & 117 & 100 & & \\
\hline
\end{tabular}

Sumber: Data Primer, 2019

risiko hipertensi pada $\mathrm{SAD}$ adalah usia dan pola makan dengan p-value 0,010. Faktor dominan penyebab hipertensi adalah usia, seseorang yang berusia $\geq 40$ tahun berisiko 4,63 kali lebih besar untuk menderita hipertensi dibandingkan usia $<40$ tahun setelah dikontrol oleh variabel pola makan (Tabel 4). Model akhir yang terbentuk terhadap kejadian DM pada SAD adalah usia, jenis kelamin, riwayat keluarga, pola makan, merokok dan aktivitas fisik dengan p-value 0,415 . Faktor dominan penyebab terjadinya DM adalah pola makan. SAD yang memiliki pola makan tidak baik berisiko 11,23 kali untuk menderita DM dibandingkan SAD yang memiliki pola makan baik setelah dikontrol variabel usia, jenis kelamin, riwayat keluarga, merokok dan aktivitas fisik. Usia $\geq 40$ tahun berisiko 2,63 kali lebih besar menderita diabetes mellitus tipe II dibandingkan usia $<40$ tahun, setelah dikontrol oleh variabel jenis kelamin, riwayat kelurga, pola makan, merokok dan aktivitas fisik. SAD yang kurang aktif melakukan aktivitas fisik berisiko 2,17 kali lebih besar menderita DM dibandingkan yang aktif melakukan aktivitas fisik, setelah dikontrol variabel usia, jenis kelamin, riwayat keluarga, pola makan dan merokok. Suku anak dalam yang memiliki kebiasaan merokok berisiko 1,26 kali lebih besar menderita DM dibandingkan yang tidak merokok, setelah dikontrol oleh variabel usia, jenis kelamin, riwayat keluarga, pola makan dan aktivitas fisik. Jenis kelamin perempuan bersifat protektif terhadap laki-laki atau dengan kata lain laki-laki lebih berisiko menderita DM dibandingkan perempuan, setelah dikontrol oleh variabel usia, riwayat keluarga, pola makan, merokok dan aktivitas fisik. SAD yang memiliki riwayat keluarga DM bersifat protektif dibandingkan yang tidak memiliki riwayat keluarga DM setelah dikontrol oleh variabel usia, jenis kelamin, pola makan, merokok dan aktivitas fisik (Tabel 5).

\section{PEMBAHASAN}

Prevalensi Hipertensi dan DM pada SAD di Desa Nyogan hampir sama dengan prevalensi Hipertensi di Kabupaten Muaro Jambi, namun prevalensi DM yang terjadi pada SAD justru lebih tinggi daripada prevalensi DM tipe II di Kabupaten Muaro Jambi, hal ini erat kaitannya dengan pola makan yang sering dilakukan pada komunitas SAD. Pola makan komunitas ini adalah sangat kurang mengonsumsi sayur dan buah serta sangat gemar mengonsumsi minuman yang sangat manis seperti teh atau kopi dengan frekuensi yang sering 
Tabel 4. Model Akhir Faktor Risiko Kejadian Hipertensi pada SAD

\begin{tabular}{lccc}
\hline \multicolumn{1}{c}{ Variabel } & B & POR $(\mathbf{9 5} \% \mathbf{C I})$ & p value \\
\hline Usia & 1,53 & $4,63(1,569-13,675)$ & 0,006 \\
Pola Makan & 0,23 & $1,26(0,410-3,920)$ & 0,681 \\
\hline
\end{tabular}

Sumber: Data Primer, 2019

Tabel 5. Model Akhir Faktor Risiko Kejadian Diabetes Mellitus pada SAD

\begin{tabular}{lccc}
\hline \multicolumn{1}{c}{ Variabel } & B & POR $(\mathbf{9 5} \% \mathbf{C I})$ & $\boldsymbol{p}$ value \\
\hline Usia & 0,97 & $2,63(0,217-32,143)$ & 0,447 \\
Jenis Kelamin & $-1,16$ & $0,31(0,008-12,014)$ & 0,531 \\
Riwayat Keluarga & $-18,31$ & $0,00(0,000)$ & 0,999 \\
Pola Makan & 2,41 & $11,23(0,838-150,573)$ & 0,068 \\
Merokok & 0,23 & $1,26(0,196-8,224)$ & 0,803 \\
Aktivitas Fisik & 0,77 & $2,17(0,121-38,974)$ & 0,598 \\
\hline
\end{tabular}

Sumber: Data Primer, 2019

(dua atau tiga kali sehari). Hal ini menjadi salah satu faktor yang terbukti berhubungan dengan kejadian DM tipe II di komunitas SAD pada penelitian ini. ${ }^{14}$

Prevalensi hipertensi berdasarkan data Dinas Kesehatan Kabupaten/Kota tahun 2017 sebesar 4,79\%, sementara prevalensi DM tipe II berdasarkan data Kementerian Kesehatan RI tahun 2013 sebesar $0,3 \%{ }^{10,6}$ Berbeda dengan prevalensi pada Komunitas Adat Terpencil di Fulani tahun 2013 yang justru lebih tinggi yaitu sebesar 31,1\%. Populasi wanita yang lebih tua lebih banyak menderita hipertensi dibandingkan pria yang lebih tua. Selain itu, penderita hipertensi merupakan perokok aktif maupun mantan perokok dan memiliki riwayat keluarga hipertensi. ${ }^{25}$ Prevalensi yang jauh lebih tinggi yaitu pada suku Aborigin dan Torres di Far Nort Queensland tahun 2011, ditemukan prevalensi pra-hipertensi $(34,0 \%)$, hipertensi stadium I $(17,7 \%)$ dan hipertensi stadium II $(3,3 \%)$. Populasi pada penelitian ini yang menjadi faktor risiko kejadian hipertensi adalah jenis kelamin $(\mathrm{OR}=4,37 ; 95 \% \mathrm{CI}=2,92-6,54)$, kelebihan berat badan $(\mathrm{OR}=2,46 ; 95 \% \mathrm{CI}=1,53-3,97)$, obesitas $(\mathrm{OR}=4,59 ; 95 \% \mathrm{CI}=2,87-7,36)$, trigliserida tinggi $(\mathrm{OR}=2,38 ; 95 \% \mathrm{CI}=1,61-3,52) .{ }^{27}$

Prevalensi DM tipe II pada SAD di Desa Nyogan menunjukkan prevalensi yang lebih tinggi dibandingkan prevalensi pada populasi umum didukung dengan data survei nasional menunjukkan bahwa prevalensi diabetes 3-5 kali lebih tinggi di First Nations daripada populasi umum dengan prevalensi $26 \%$ berdasarkan hasil skrining di ma- sing-masing komunitas. ${ }^{26}$ Berdasarkan data dari profil status kesehatan di Manitoba menunjukkan prevalensi DM pada komunitas adat terpencil sebesar 11,8\% lebih tinggi dibandingkan dengan populasi umum sebesar $8,8 \%{ }^{26}$

Hasil penelitian ini menemukan bahwa terjadi perubahan pola penyakit pada SAD. Selama ini penyakit yang sering diderita SAD didominasi oleh penyakit infeksi, tetapi saat ini prevalensi penyakit tidak menular sudah meningkat dan hampir sama dengan prevalensi kejadian penyakit tidak menular pada populasi masyarakat umum. Hal ini menunjukkan bahwa adanya transisi epidemiologi yang juga mempengaruhi transisi lingkungan dan sosial yang erat kaitannya dengan pola morbiditas atau status kesehatan masyarakat. Hasil penelitian ini menemukan bahwa faktor risiko hipertensi adalah usia dan pola makan. Faktor dominan yang menjadi faktor risiko hipertensi pada suku anak dalam adalah usia. Seseorang yang berusia $\geq 40$ tahun memiliki risiko lebih besar untuk menderita hipertensi dibandingkan yang berusia $<40$ tahun setelah dikontrol oleh pola makan. SAD dengan usia lebih dari 40 tahun dengan pola makan buruk akan lebih memperbesar risiko terjadinya hipertensi, dibandingkan usia lebih muda dan dengan pola makan yang baik.

Hasil ini sejalan dengan teori yang menyatakan bahwa semakin bertambah tua, dinding arteri akan mengalami penebalan karena adanya penumpukan zat kolagen pada lapisan otot sehingga pembuluh darah akan berangsur-angsur menyempit dan menjadi kaku. Hipertensi merupakan salah 
satu penyakit degeneratif, dengan bertambahnya umur maka tekanan darah juga akan meningkat, yang disebabkan beberapa perubahan fisiologis. Proses fisiologis terjadi peningkatan resistensi prefier dan peningkatan aktivitas simpatik, dinding arteri akan mengalami penebalan karena kolagen yang menumpuk pada lapisan otot, sehingga pembuluh darah berangsur menjadi sempit dan kaku. Selain itu, sensitivitas pengatur tekanan darah yaitu refleks baroreseptor mulai berkurang, demikian juga halnya dengan peran ginjal. Aliran darah ginjal dan laju filtrasi glomerulus menurun, hal ini memicu terjadinya hipertensi. ${ }^{28}$

Penelitian ini sejalan dengan hasil penelitian yang dilakukan Pradono yang menemukan bahwa faktor dominan terhadap kejadian hipertensi adalah usia. Seseorang yang berusia 45 tahun atau lebih berisiko 2,40 kali menderita hipertensi dibandingkan seseorang berusia kurang dari 45 tahun setelah dikontrol oleh variabel status kawin, status ekonomi, lama merokok, berat badan lebih, lingkar perut, hiperglikemia, gangguan mental, makanan panggang dan pengawet. ${ }^{29}$ Namun, hasil ini tidak sejalan dengan penelitian yang dilakukan oleh Andika dan Safitri di Rumah Sakit Umum Daerah dr. Zainoel Abidin Provinsi Aceh pada tahun 2018 menemukan bahwa faktor dominan yang berhubungan dengan kejadian hipertensi adalah riwayat keluarga. Seseorang yang memiliki riwayat keluarga hipertensi memiliki peluang tujuh kali lebih besar menderita hipertensi dibandingkan seseorang yang tidak memiliki riwayat keluarga hipertensi setelah dikontrol oleh variabel umur. ${ }^{30}$

Faktor lain yang meningkatkan risiko terjadinya hipertensi pada SAD adalah pola makan setelah dikontrol dengan usia. Hasil penelitian ini sejalan dengan penelitian yang dilakukan Anwar di Puskesmas S.Parman Kota Banjarmasin menemukan bahwa ada hubungan yang bermakna antara jumlah konsumsi buah dan sayur. Seseorang yang kurang mengonsumsi buah dan sayur berpeluang 6,41 kali menderita hipertensi dibandingkan seseorang yang cukup mengonsumi buah dan sayur. ${ }^{31}$ Namun, penelitian ini tidak sejalan dengan penelitian yang dilakukan Mahmudah, dkk di Kelurahan Sawangan Baru Kota Depok tahun 2015 yang menunjukkan asupan lemak merupakan faktor dominan yang mempengaruhi kejadi- an hipertensi. Seseorang yang asupan natriumnya berlebih berisiko 4,62 kali lebih besar menderita hipertensi dibandingkan seseorang yang asupan natriumnya baik setelah dikontrol oleh variabel asupan lemak. ${ }^{32}$

Penyakit tidak menular itu bersifat multikausal, sehingga apabila seseorang berusia $\geq 40$ tahun dan memiliki pola makan yang tidak baik, maka akan memperbesar risiko untuk terkena hipertensi. Sehingga jika seseorang telah berusia $\geq 40$ tahun agar menerapkan pola hidup sehat seperti mengatur pola makan dengan makan beraneka ragam, seimbang dan sehat. Hasil penelitian ini juga menemukan bahwa faktor risiko DM adalah usia, jenis kelamin, riwayat keluarga, pola makan, merokok dan aktivitas fisik dimana faktor dominan penyebab DM adalah pola makan. SAD yang memiliki pola makan tidak baik berisiko 11,23 kali menderita DM dibandingkan SAD yang memiliki pola makan baik setelah dikontrol variabel usia, jenis kelamin, riwayat keluarga, merokok dan aktivitas fisik.

Pola makan penderita DM tipe II pada SAD yang meliputi konsumsi buah dan sayur, makanan berisiko (minuman manis dan bumbu penyedap), keragaman konsumsi pangan dan asupan energi didapatkan hasil bahwa mayoritas SAD tidak pernah mengonsumsi buah-buahan segar dalam satu minggu $(66,7 \%)$ dan untuk porsi rata-rata konsumsi buah-buahan segar hanya mengonsumsi satu porsi dalam satu hari $(33,7 \%)$ sedangkan untuk konsumsi sayur-sayuran mayoritas SAD sudah mengonsumsi setiap hari $(66,7 \%)$ namun hanya satu porsi per hari $(66,7 \%)$ sehingga konsumsi buah dan sayur penderita hipertensi pada SAD dalam $100 \%$ tidak baik karena mengonsumsi buah dan/atau sayur kurang dari lima porsi per hari selama tujuh hari dalam seminggu.

Hasil analisis terhadap pola makan SAD terkait konsumsi makanan berisiko meliputi minuman manis dan bumbu penyedap, sebagian besar SAD mengonsumsi minuman manis 1 kali per hari $(66,7 \%)$ dan bumbu penyedap 1 kali per hari $(100 \%)$. Selain itu, keragaman konsumsi pangan yang dinilai dari skor konsumsi pangan, rata-rata penderita DM pada SAD memiliki skor 228,33 yang menunjukkan diatas skor konsumsi pangan rata-rata populasi yaitu sebesar 214,59 dan rata-rata asupan energi SAD yaitu $1153,53 \mathrm{kkal} / \mathrm{kap} / \mathrm{hari}$, 
angka ini berada di bawah standar angka kecukupan energi menurut Kepmenkes 1593/2005 yaitu $2.000 \mathrm{kkal} / \mathrm{kap} / \mathrm{hari} .{ }^{33}$

Kualitas dan jumlah makanan yang dikonsumsi masyarakat mempengaruhi kejadian diabetes, hal ini dikarenakan kebanyakan SAD tergolong tidak baik dalam mengonsumsi makanan. Berdasarkan hasil penelitian, SAD mengonsumsi makanan dalam jumlah banyak, tetapi tidak memenuhi kalori setiap waktu makan yang telah ditentukan. Makanan memegang peran dalam kejadian DM tipe II. Pentingnya dalam memperhatikan jumlah makanan yang dikonsumsi karena apabila jumlah makanan yang dikonsumsi tidak sesuai dengan pemenuhan kebutuhan yang telah ditentukan akan menyebabkan terjadinya DM tipe II. Selain itu, pola makan yang tinggi garam, gula dan lemak mengakibatkan masyarakat mengonsumsi makanan secara berlebihan, terlebih makanan yang serba instan saat ini sangat digemari oleh sebagian masyarakat yang dapat meningkatkan kadar gula darah. ${ }^{34}$

Hasil studi ini sejalan dengan penelitian yang dilakukan Zulfah, dkk di Kelurahan Mudung Laut Kota Jambi tahun 2015 model akhir yang dihasilkan adalah konsumsi tinggi karbohidrat, konsumsi tinggi protein dan kurang sayur dan buah faktor dominan yang menjadi penyebab DM tipe II adalah kurang sayur dan buah setelah dikontrol oleh variabel konsumsi tinggi karbohid- rat dan konsumsi tinggi protein. Hasil uji statistik menunjukkan nilai (p-value 0,001; POR 95\% CI 18,023 $(3,981-81,671))$ yang berarti seseorang yang mengonsumsi sayur dan buah $<25$ gram berisiko 18 kali menderita DM tipe II dibandingkan seseorang yang mengonsumsi sayur dan buah $\geq 25$ gram. ${ }^{35}$ Berbeda dengan penelitian yang dilakukan Wardiah dan Emilia di wilayah kerja Puskesmas Langsa Lama Kota Langsa, Aceh pada tahun 2017 menghasilkan model akhir yaitu umur, riwayat keluarga, pola makan dan indeks massa tubuh dengan faktor dominan yang menjadi penyebab DM tipe II adalah umur setelah dikontrol oleh variabel riwayat keluarga, pola makan dan indeks massa tubuh. Meskipun pola makan bukan merupakan faktor dominan penyebab DM tipe II, tetapi hasil uji statistik menunjukkan bahwa pola makan berhubungan dengan kejadian DM tipe 2 (p-value 0,045 ; OR 2,75) yang artinya, seseorang dengan pola makan berlebih berpeluang 2,75 kali menderita diabetes mellitus tipe II dibandingkan seseorang dengan pola makan sesuai atau kurang. ${ }^{36}$

Penyakit degeneratif itu bersifat multikausal, sehingga bila seseorang memiliki pola makan yang tidak baik, berusia $\geq 40$ tahun, kurang melakukan aktivitas fisik dan memiliki kebiasaan merokok maka akan memperbesar risiko untuk terkena DM tipe II. Sehingga sebagai upaya pencegahan, jika seseorang telah berusia $\geq 40$ tahun supaya menerapkan pola hidup sehat, se- perti mengatur pola makan, memperhatikan jenis makanan yang dikonsumsi serta energinya. Serta melakukan aktivitas fisik yang cukup dan tidak merokok.

\section{KESIMPULAN DAN SARAN}

Besar masalah penyakit tidak menular pada SAD sama dengan prevalensi pada komunitas umum yaitu prevalensi hipertensi sebesar 4,32\% dan DM tipe II $0,72 \%$. Faktor dominan yang berhubungan dengan kejadian hipertensi adalah usia, seseorang yang berusia $\geq 40$ tahun lebih berisiko menderita hipertensi setelah dikontrol variabel pola makan. Faktor dominan penyebab DM tipe II adalah pola makan. Pola makan yang tidak baik meningkatkan risiko sebesar 11,23 kali untuk menderita DM setelah dikontrol variabel umur, jenis kelamin, riwayat keluarga, merokok dan aktivitas fisik.

Masyarakat khususnya SAD perlu menerapkan pola makan yang baik seperti rendah lemak, rendah manis, tinggi serat (konsumsi sayur dan buah) yang beraneka ragam, terutama ketika usianya lebih atau sama dengan 40 tahun. Dinas kesehatan melalui puskesmas perlu meningkatkan upaya promotif dan preventif seperti pendidikan kesehatan untuk mengenali faktor risiko kejadian hipertensi dan DM tipe II, menjalankan puskesmas keliling untuk pemeriksaan kesehatan secara gratis dalam kurun waktu seminggu sekali dan membentuk kader untuk menjalankan Pos Pembinaan Terpadu Penyakit Tidak Menular (Posbindu PTM) pada komunitas adat terpencil yang memiliki banyak keterbatasan.

\section{UCAPAN TERIMA KASIH}

Peneliti mengucapkan terima kasih kepada Ketua Lembaga Penelitian dan Pengabdian kepada Masyarakat Universitas Jambi yang telah mem- 
berikan dana pada penelitian ini. Ucapan te-rima kasih juga disampaikan kepada kepala Desa Nyogan beserta perangkatnya, bidan Desa Nyogan serta tim enumerator Fakultas Kesehatan Masyarakat Universitas Jambi yang telah membantu pelaksanaan penelitian ini.

\section{DAFTAR PUSTAKA}

1. Minor Global Health. Double Burden ofDisease. Amsterdam: Vrje Universiteit Amsterdam; 2016. Available at: https://studiegids.vu.nl/ en/Minor/2018-2019/global-health/AB 1109

2. Kemenkes RI. Infodatin Hipertensi. Jakarta: Kementerian Kesehatan RI; 2014.

3. Kemenkes RI. Infodatin Situasi dan Analisis Diabetes. Jakarta: Kementerian Kesehatan RI; 2014.

4. Kemenkes RI. Sebagian Besar Penderita Hipertensi Tidak Menyadarinya. Jakarta: Kementerian Kesehatan RI; 2017.

5. World Health Organization. Diabetes Fakta dan Angka. 2016.

6. Kemenkes RI. Riskesdas 2013. Jakarta: Badan Peneliti dan Pengembangan Kesehatan Kementerian Kesehatan RI; 2013.

7. Kemenkes RI. Hasil Utama Riskesdas Tentang Prevalensi Diabetes Mellitus di Indonesia 2018. Jakarta: Kementerian Kesehatan RI; 2018.

8. Dinkes Jambi. Pengukuran Tekanan Darah Penduduk $\geq 18$ tahun Menurut Jenis Kelamin, Kecamatan dan Puskesmas Provinsi Jambi. Jambi: Dinas Kesehatan; 2015.

9. Dinkes Jambi. Pengukuran Tekanan Darah Penduduk $\geq 18$ tahun Menurut Jenis Kelamin, Kecamatan dan Puskesmas Provinsi Jambi. Jambi: Dinas Kesehatan; 2016.

10. Dinkes Jambi. Pengukuran Tekanan Darah Penduduk $\geq 18$ tahun Menurut Jenis Kelamin, Kecamatan dan Puskesmas Provinsi Jambi. Jambi: Dinas Kesehatan; 2017.

11. Irwan. Epidemiologi Penyakit Tidak Menular. Yogyakarta: Deepublish; 2016.

12. Movanita ANK. Lama Hidup Nomaden, Kini Suku Anak Dalam Punya Hunian Tetap. [Report Online]. [Diakses pada 19 Februari 2017]. Available at: Kompas.com.

13. Dinsos TK dan Transmigrasi. Profil Komunitas Adat Terpencil dan Program Pember- dayaan KAT di Provinsi Jambi. Jambi: Dinas Sosial Tenaga Kerja dan Transmigrasi; 2013.

14. Kalsum U, Halim R, Fitri A. Pola Perkawinan, Pola Konsumsi dan Status Gizi Balita Orang Rimba di Desa Sungai Terap dan Hajran. Jurnal Kesmas Jambi. 2018;2(2):87-96.

15. Sartik, Tjekyan RS, Zulkarnain M. Faktor-Faktor Risiko dan Angka Kejadian Hipertensi pada Penduduk Palembang. Jurnal Ilmu Kesehatan Masyarakat. 2017;8(3):180-191.

16. Kusumawaty J, Hidayat N, Ginanjar E. Hubungan Jenis Kelamin dengan Intensitas Hipertensi. Mutiara Medika. 2016;16(2):4651.

17. Thaha IL, Widya A, Dian SA. Kejadian Hipertensi di Wilayah Kerja Puskesmas Segeri Kabupaten Pangkep. Jurnal Media Kesehatan Masyarakat Indonesia. 2016;12(2):104-110.

18. Heriziana. Faktor Risiko Kejadian Penyakit Hipertensi di Puskesmas Basuki Rahmat Palembang. Jurnal Kesmas Jambi. 2017;1(1):31-39.

19. Manawan AA, Rattu AJM, Punuh MI. Hubungan antara Konsumsi Makanan dengan Kejadian Hipertensi di Desa Tandengan Satu Kecamatan Eris Kabupaten Minahasa. Jurnal Ilmiah Farmasi. 2016;5(1):340-347.

20. Santosa LHK, Chasani S, Pramudo SG. Faktor Risiko Kejadian Hipertensi di Puskesmas Kenduruan, Kabupaten Tuban. Jurnal Kedokteran Diponegoro. 2016;5(4):1182-1191.

21. Fathurohman I, Fadhilah M. Gambaran Tingkat Risiko dan Faktor-Faktor yang Berhubungan dengan Risiko Diabetes Mellitus Tipe 2 di Buaran, Serpong. Jurnal Kedokteran YARSI. 2016;24(3):186-202.

22. Hengky, dkk. Hubungan Pola Makan de-ngan Insidensi Diabetes Mellitus Tipe 2 pada Wanita Usia Dewasa di RSUD Andi Makkasau Kota Parepare. Jurnal Ilmiah Manusia dan Kesehatan. 2018;1(1):34-41.

23. Kurniawaty E, Yanita B. Faktor-Faktor yang Berhubungan dengan Kejadian Diabetes Melitus Tipe II. J Medical Journal of Lampung University. 2016;5(2):27-31.

24. Kusnadi G, Murbawani EA, Fitranti DY. Faktor Risiko Diabetes Mellitus pada Petani dan Buruh. Journal of Nutrition College. 2017;6(2):138-148. 
25. Nyuyki CK, Ngufor G, Mbeh G, Mbanya JC. Epidemiology of Hypertension in Fulani Indigenous populations-Age, Gender and Drivers. Journal of Health, Population and Nutrition. 2017;1-12.

26. Harris SB, Bhattacharyya O, Dyck R, Hayward MN, Toth EL. Type 2 Diabetes in Aboriginal Peoples. Canadian Diabetes Association. 2013;37:191-196.

27. Esler D, Raulli A, Pratt R, Fagan P. Hypertension: High Prevalence and Positive Association with Obesity among Aboriginal and Torres Strait Islander Youth in far North Queensland. 2016;40(1):65-69.

28. Kurniasih I, Setiawan MR. Analisis Faktor Risiko Kejadian Hipertensi di Puskesmas Srondol Semarang Periode Bulan September-Oktober 2011. Jurnal Kedokteran Muhammadiyah. 2013;1(2):54-59.

29. Pradono J, Indrawati L, Murnawan T. Permasalahan dan Faktor Risiko yang Berhubungan dengan Terjadinya Hipertensi di Kabupaten Bogor Provinsi. Jawa Barat. Buletin Penelitian Kesehatan. 2013;41(2):61-71.

30. Andika F, Safitri F. Faktor Risiko Kejadian Hipertensi di Rumah Sakit Umum Daerah dr. Zainoel Abidin Provinsi Aceh. Journal of Healthcare Technology and Medicine. 2019;5(1):148-161.

31. Anwar R. Konsumsi Buah dan Sayur serta
Konsumsi Susu Sebagai Faktor Risiko Terjadinya Hipertensi di Puskesmas S. Parman Kota Banjarmasin. Jurnal Skala Kesehatan. 2014;5(1).

32. Mahmudah S, Maryusman T, Arini FA, Malkan I. Hubungan Gaya Hidup dan Pola Makan dengan Kejadian Hipertensi pada Lansia di Kelurahan Sawangan Baru Kota Depok tahun 2015. Jurnal Biomedika. 2016;8(2):39-47.

33. Hariyanto B, Sugiatmi, Gantina A, Maulad A. Perkembangan Konsumsi Pangan. [e-book]. 2018.

34. Sudaryanto A, Setiyadi NA, Frankilawati DA. Hubungan antara Pola Makan, Genetik dan Kebiasaan Olahraga terhadap Kejadian Diabetes Mellitus tipe II di Wilayah Kerja Puskesmas Nusukan, Banjarsari. Prosiding Seminar Nasional Sains dan Teknologi. 2014;1(1):19-24.

35. Zulfah S, Syukri M, Hadisaputro S, Adi MS, Nugroho H, Setiawati MM. Karbohidrat dalam Makanan Khas Melayu Jambi Diwaspadai sebagai Faktor Risiko Diabetes Melitus tipe 2. Journal of Health Care Media. 2016;2(5):1-7.

36. Wardiah, Emilia E. Faktor Risiko Diabetes Mellitus pada Wanita Usia Reproduktif di Wilayah Kerja Puskesmas Langsa Lama Kota Langsa, Aceh. Jurnal Kesehatan Global. 2018;1(3):119-126. 